\title{
Low birthweight infants and total parenteral nutrition immediately after birth. II. Randomised study of biochemical tolerance of intravenous glucose, amino acids, and lipid
}

\author{
N Murdock, A Crighton, L M Nelson, J S Forsyth
}

\begin{abstract}
This randomised study aimed to compare the biochemical tolerance of three parenteral regimens administered during the first 48 hours of life. Twenty nine infants were randomised to either: (a) glucose $10 \%$; (b) glucose $10 \%$ /amino acids; (c) glucose $10 \% /$ amino acids/lipid. Blood samples for plasma amino acid profiles, cholesterol, and triglyceride concentrations were taken on arrival in the neonatal unit and again between 36 and 48 hours of life. Arterial or capillary blood gas analysis and blood glucose estimates were performed routinely during the first 48 hours of life. There was a sharp decline in plasma amino acid concentrations in the group following (a) compared with the two groups following (b) and (c) regimens. In all groups plasma triglyceride and cholesterol were not significantly different before and after 48 hours of lipid infusion. Peak mean (SE) bilirubin concentrations (203 (12) $v 181$ (19) $v 220$ (20) $\mu \mathrm{mol} / /$ ) and the need for phototherapy (nine $v$ eight $v$ five infants) were similar for each of the groups. Hypoglycaemia occurred most frequently during the (b) regimen and least commonly in the (c) group.

There are potential health gains from giving parenteral nutrition to low birthweight infants immediately after birth, and this study indicates that restriction of nutritional intake immediately after birth in preterm infants may cause significant metabolic disturbance. This can be prevented by starting a regimen of intravenous amino acids and lipid immediately after birth.
\end{abstract}

(Arch Dis Child 1995; 73: F8-F12)

Keywords: total parental nutrition, low birthweight infant, fat emulsion, amino acid solutions.

Department of Child Health, Ninewells Hospital and Medical School, Dundee DD1 9SY

N Murdock

A Crighton

J S Forsyth

Department of Biochemical Medicine L $M$ Nelson

Correspondence to: Dr Forsyth.

Accepted 30 April 1995

Intravenous nutrition continues to have an important role in the management of sick preterm infants. For many years infants requiring total parenteral nutrition (TPN) have traditionally been given initially a glucose solution and subsequently amino acids and lipid emulsion gradually introduced towards the end of the first week of life. ${ }^{1}$ This cautious approach originates from the earliest developments in neonatal TPN regimens when there was concern that immaturity of intermediate metabolism would limit tolerance of parenteral fluids. ${ }^{23}$ A consequence of this approach is that the nutritional needs of the infant are not being met during the first days of life, when the infant is frequently most sick and in need of optimal nutrition. ${ }^{4}$ With increasing recognition that early diet may not only impact on immediate survival ${ }^{5}$ but also influence long term wellbeing, ${ }^{6}$ the need for a significant interruption in the nutritional supply of the newborn infant at such a vital time merits further consideration.

Over the past 20 years, there have been considerable improvements in the quality of nutritional fluids. Metabolic complications associated with the earlier amino acid solutions ${ }^{78}$ are now less common. However, there is still concern that some solutions are associated with potentially dangerous concentrations of plasma phenylalanine and tyrosine. ${ }^{9}$ Early concerns that lipid solutions might increase the risk of kernicterus ${ }^{10}$ have been followed by reports that fat emulsions may seriously impair lung function. ${ }^{1112}$ However, more recently, others have reported that polyunsaturated fats present in fat emulsion may have a vital role in protecting immature lungs from oxygen toxicity. ${ }^{13}$ Furthermore, the important part played by long chain polyunsaturated fatty acids (LCPs) in the development of visual and cortical function is increasingly being recognised. ${ }^{14} 15$ Essential fatty acid stores in preterm infants are low at birth, and in the absence of lipid intake fatty acid deficiency may occur within five days. ${ }^{16}$

From these data it can be concluded that there are potential health gains to be achieved from the earlier administration of parenteral nutrients, provided that the parenteral fluids are tolerated by the infant. Separate studies suggest that preterm infants can tolerate intravenous amino acids ${ }^{17}$ and fat emulsion ${ }^{18}$ immediately after birth. We undertook a randomised study to compare directly the biochemical tolerance of three parenteral 
Table 1 Planned fluid, nutrient, and energy intake during study regimens

\begin{tabular}{|c|c|c|c|c|c|c|c|c|c|c|}
\hline \multirow[b]{2}{*}{ Regimen } & \multicolumn{2}{|c|}{$\begin{array}{l}\text { Total fluid } \\
(\mathrm{m} / \mathrm{kg} / \mathrm{d})\end{array}$} & \multicolumn{2}{|c|}{$\begin{array}{l}\text { Glucose } \\
(g / k g / d)\end{array}$} & \multicolumn{2}{|c|}{$\begin{array}{l}\text { Amino acid } \\
(g / k g / d)\end{array}$} & \multicolumn{2}{|c|}{$\begin{array}{l}F a t \\
(g / k g / d)\end{array}$} & \multicolumn{2}{|c|}{$\begin{array}{l}\text { Non-protein energy } \\
(\text { kcal/kg/d) }\end{array}$} \\
\hline & Day 1 & Day 2 & Day 1 & Day 2 & Day 1 & Day 2 & Day 1 & Day 2 & Day 1 & Day 2 \\
\hline $\begin{array}{l}a \\
b \\
c\end{array}$ & $\begin{array}{l}70 \\
70 \\
70\end{array}$ & $\begin{array}{l}100 \\
100 \\
100\end{array}$ & $\begin{array}{l}7 \\
7 \\
7\end{array}$ & $\begin{array}{l}10 \\
10 \\
10\end{array}$ & $\begin{array}{l}1.0 \\
1.0\end{array}$ & $\begin{array}{l}1.4 \\
1.4\end{array}$ & 1.0 & $1 \cdot 0$ & $\begin{array}{l}28 \\
28 \\
38\end{array}$ & $\begin{array}{l}40 \\
40 \\
50\end{array}$ \\
\hline
\end{tabular}

Table 2 Characteristics of infants

\begin{tabular}{lclll}
\hline Regimen & $n=$ & $\begin{array}{l}\text { Sex } \\
(M / F)\end{array}$ & $\begin{array}{l}\text { Gestation } \\
\text { weeks }(S E)\end{array}$ & $\begin{array}{l}\text { Birthweight } \\
(g)(S E)\end{array}$ \\
\hline a & 11 & $7 / 4$ & $31 \cdot 0(0 \cdot 7)$ & $1340(97)$ \\
b & 10 & $9 / 1$ & $32 \cdot 8(0 \cdot 9)$ & $1498(97)$ \\
c & 8 & $4 / 4$ & $31 \cdot 8(0 \cdot 6)$ & $1635(108)$ \\
\hline
\end{tabular}

to receive one of three intravenous fluid regimens: (a) glucose $10 \%$; (b) glucose $10 \%$ /amino acids (Vamin 9, Pharmacia, Milton Keynes, UK); (c) glucose 10\%/amino acids/lipid (Vamin 9). The planned intakes of the three regimens are shown in table 1 . If clinically indicated, fluid intakes were altered by the clinicians responsible for the care of the infants.

The Unit protocol for neonatal hypoglycaemia determined that if a plasma glucose of less than $2.6 \mathrm{mmol} / 1$ was recorded intravenous glucose load should be increased to $10 \mathrm{mg} / \mathrm{kg} / \mathrm{minute}$, and if this did not maintain an adequate plasma glucose, glucagon was to be administered intravenously. Infants fed more than $1 \mathrm{ml} /$ hour of expressed breast milk or formula were withdrawn from the study.

Blood samples for plasma amino acid profiles, cholesterol, and triglyceride concentrations were taken on arrival in the neonatal unit and again between 36 and 48 hours of life. The results from the initial samples taken within an hour of delivery, provided a baseline 'normal range' against which the 48 hour concentrations were compared. Amino acid analysis was carried out by anion exchange chromatography with ninhidrin detection on a Chromakon 500 Amino Acid Analyser (Kontron Instruments, Watford, UK). Cholesterol and triglyceride assays were performed using standard enzymatic methods on a Cobas Fara analyser (Roche Diagnostic Systems, Welwyn Garden City, UK). Arterial or capillary blood gas analysis and blood glucose estimates were performed routinely during the first 48 hours of life.

\section{Results}

Out of 44 infants entered into the study 15 rapidly progressed to milk feeding and were withdrawn, leaving 11 in group a, 10 in group b, and eight in group c. Infant characteristics are shown in table 2 . The gestations were similar and although there was variation in birthweight among the groups the differences were not significant. The actual fluid and nutrient intakes received by the infants are shown in table 3. Hypoglycaemia requiring an increase in glucose load occurred most commonly within the first 24 hours and was most frequent during the (b) regimen and least common in the (c) group (table 4). The mean centiles for plasma glucose concentrations during each of the regimens are recorded in table 4.

When the glucose load was increased in hypoglycaemic infants receiving the (b) solution, there was a concomitant increase in the amino acid intake of these infants (table 3 ). In each group there was a decline in plasma amino acid concentrations compared with the initial baseline measurements (table 5; figs 1-3). This was most obvious in the (a) group, with only tyrosine and phenylalanine above the baseline level. In all groups plasma triglyceride and cholesterol were not significantly different before and after 48 hours of lipid infusion (table 6). Peak mean (SE) bilirubin concentrations (203 (12) v 181 (19) v $220(20) \mu \mathrm{mol} / \mathrm{l})$ and the need for phototherapy (nine $v$ eight $v$ five infants) were similar for each of the groups.

\section{Discussion}

This study shows that moderate intakes of intravenous amino acids and fat emulsion can be tolerated immediately after birth by low birthweight infants.

There was a rapid decline in plasma amino acid concentrations during the first days of life in infants not receiving amino acids as part of their parenteral nutrition regimen. In those infants who did receive amino acids there were negative differences for some of the amino acids but the overall profile was much closer to baseline values. The amino acid profile of the infants receiving lipid in addition to amino acids (c) did not significantly differ from the infants receiving only glucose with amino acid (b).

Measurements of plasma amino acids rapidly reflect short term dietary manipulations, including protein restriction. ${ }^{19}$ In a

Table 3 Actual fluid, nutrient, and energy intake during study regimens

\begin{tabular}{|c|c|c|c|c|c|c|c|c|c|c|}
\hline \multirow[b]{2}{*}{ Regimen } & \multicolumn{2}{|l|}{$\begin{array}{l}\text { Total fluid } \\
(\mathrm{ml} / \mathrm{kg} / \mathrm{d})\end{array}$} & \multicolumn{2}{|l|}{$\begin{array}{l}\text { Glucose } \\
(\mathrm{g} / \mathrm{kg} / \mathrm{d})\end{array}$} & \multicolumn{2}{|l|}{$\begin{array}{l}\text { Amino acid } \\
(\mathrm{g} / \mathrm{kg} / \mathrm{d})\end{array}$} & \multicolumn{2}{|l|}{$\begin{array}{l}F a t \\
(g / k g / d)\end{array}$} & \multicolumn{2}{|c|}{$\begin{array}{l}\text { Non-protein energy } \\
\text { (kcal/kg/d) }\end{array}$} \\
\hline & Day 1 & Day 2 & Day 1 & Day 2 & Day 1 & Day 2 & Day 1 & Day 2 & Day 1 & Day 2 \\
\hline $\begin{array}{l}a \\
b \\
c\end{array}$ & $\begin{array}{l}86 \cdot 9(7 \cdot 7) \\
90 \cdot 2(11 \cdot 7) \\
77 \cdot 9(8 \cdot 8)\end{array}$ & $\begin{array}{r}102 \cdot 5(4 \cdot 1) \\
102 \cdot 2(7 \cdot 9) \\
99 \cdot 5(6 \cdot 0)\end{array}$ & $\begin{array}{l}8 \cdot 6(0 \cdot 76) \\
9 \cdot 21(1 \cdot 17) \\
7 \cdot 27(0 \cdot 89)\end{array}$ & $\begin{array}{l}10.74(0.49) \\
10.39(0.81) \\
10.17(0.76)\end{array}$ & $\begin{array}{l}1.35(0.17) \\
1.06(0.13)\end{array}$ & $\begin{array}{l}1 \cdot 51(0 \cdot 12) \\
1 \cdot 31(0 \cdot 11)\end{array}$ & $0.87(0.03)$ & $0.91(0.06)$ & $\begin{array}{l}34 \cdot 4(3 \cdot 0) \\
38 \cdot 2(4 \cdot 1) \\
40 \cdot 0(4 \cdot 4)\end{array}$ & $\begin{array}{l}43.0(2.2) \\
42.6(3.0) \\
53.8(5.6)\end{array}$ \\
\hline
\end{tabular}

Values: means (SE). 
Table 4 Centiles for plasma glucose and number of hypoglycaemia intervention

\begin{tabular}{|c|c|c|c|c|}
\hline \multirow[b]{2}{*}{ Regimen } & \multicolumn{3}{|l|}{ Centiles } & \multirow{2}{*}{$\begin{array}{l}\text { Hypoglycaemia } \\
\text { interventions }\end{array}$} \\
\hline & 10th & $50 t h$ & 90th & \\
\hline $\begin{array}{l}\mathrm{a} \\
\mathrm{b} \\
\mathrm{c}\end{array}$ & $\begin{array}{l}2.88(0 \cdot 16) \\
2.57(0 \cdot 17) \\
2.67(0.19)\end{array}$ & $\begin{array}{l}3.61(0.24) \\
3.14(0.06) \\
3.36(0.25)\end{array}$ & $\begin{array}{l}4.64(0.31) \\
4.47(0.22) \\
4.21(0.37)\end{array}$ & $\begin{array}{l}6 \\
9 \\
2\end{array}$ \\
\hline
\end{tabular}

Values: $\mathrm{mmol} / \mathrm{l}(\mathrm{SE}) .{ }^{\star}$ No of study days during each regimen in which hypoglycaemia protocol initiated.

previous study comparing glucose alone with glucose and amino acids, at the end of the first week of life the plasma amino acid pattern in the glucose alone group resembled that seen in infants with protein malnutrition states, the essential amino acid concentrations being substantially lowered and non-essential amino acids being maintained closer to normal levels by endogenous protein breakdown. ${ }^{20}$ In our study the amino acid profile of group (a) showed low values for both essential and nonessential amino acids. Our infants were studied during the first 48 hours of life and therefore, in addition to the lack of supply of amino acids, the infants were also subject to the metabolic milieu which prevails immediately after birth. High insulin concentrations at this time might have enhanced muscle uptake of amino acids and reduced protein breakdown. ${ }^{21}$ It has been shown before that preterm infants with respiratory distress syndrome who receive amino acids during the first day of life achieve significant nitrogen retention compared with infants receiving glucose alone who are in negative balance. ${ }^{22}$ Mitton and colleagues demonstrated that immediately after birth, infants receiving glucose alone were not only in negative nitrogen balance but also that protein turnover was lower in the sickest infants. ${ }^{23}$ Although glucose administration does reduce the catabolic effect, the available evidence indicates that parenteral feeding regimens devoid of amino acids will inevitably result in negative nitrogen balance. ${ }^{24}$ Studies of parenterally fed puppies have shown that patterns of free amino acids in organ tissues, including that of the brain, tend to mirror plasma amino acid profiles, ${ }^{25}$ but whether a relatively brief period of

Table 5 Baseline plasma amino acid concentrations and profiles during study regimens

\begin{tabular}{|c|c|c|c|c|}
\hline & $\begin{array}{l}\text { Baseline } \\
\text { values }\end{array}$ & $\begin{array}{l}\text { Glucose alone } \\
\text { regimen (a) }\end{array}$ & $\begin{array}{l}\text { Glucose/amino } \\
\text { acid regimen (b) }\end{array}$ & $\begin{array}{l}\text { Glucose/amino acid/ } \\
\text { fat regimen (c) }\end{array}$ \\
\hline $\begin{array}{l}\text { Taurine (T) } \\
\text { Threonine (Th) } \\
\text { Serine (S) } \\
\text { Glutamate (G) } \\
\text { Glutamine (Gl) } \\
\text { Proline (P) } \\
\text { Glycine (Gy) } \\
\text { Alanine (Al) } \\
\text { Citrulline (C) } \\
\text { Valine (V) } \\
\text { Cystine (Cy) } \\
\text { Methionine (M) } \\
\text { Isoleucine (II) } \\
\text { Leucine (L) } \\
\text { Tyrosine (Ty) } \\
\text { Phenylalanine (Ph) } \\
\text { Tryptophan (Tr) } \\
\text { Ornithine (O) } \\
\text { Histidine (H) } \\
\text { Lysine (Ly) } \\
\text { Arginine (Ar) }\end{array}$ & 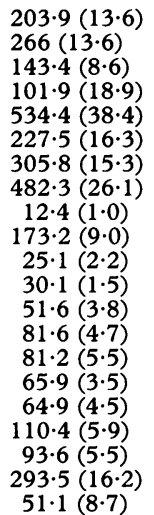 & $\begin{array}{c}48(10 \cdot 7) \\
91 \cdot 6(15 \cdot 8) \\
82(10 \cdot 2) \\
70 \cdot 6(16 \cdot 8) \\
343(128) \\
84 \cdot 6(12 \cdot 6) \\
209(23 \cdot 3) \\
132 \cdot 6(20 \cdot 7) \\
6 \cdot 5(1 \cdot 5) \\
71 \cdot 8(1 \cdot 5) \\
7 \cdot 4(1 \cdot 3) \\
13 \cdot 2(1 \cdot 3) \\
14(3 \cdot 3) \\
49(5 \cdot 3) \\
90(21) \\
100(47) \\
28 \cdot 6(7 \cdot 5) \\
41 \cdot 4(9 \cdot 3) \\
51 \cdot 8(6 \cdot 6) \\
68 \cdot 8(9 \cdot 4) \\
19(5 \cdot 5)\end{array}$ & $\begin{array}{c}46 \cdot 7(12 \cdot 4) \\
194(26 \cdot 3) \\
228(22 \cdot 8) \\
87 \cdot 4(25 \cdot 8) \\
450(40 \cdot 3) \\
324 \cdot 7(39 \cdot 5) \\
372 \cdot 8(33 \cdot 3) \\
257(41) \\
14 \cdot 7(2 \cdot 7) \\
150 \cdot 8(32 \cdot 3) \\
30(2 \cdot 4) \\
43 \cdot 5(2 \cdot 7) \\
67 \cdot 25(6 \cdot 5) \\
85 \cdot 2(10 \cdot 1) \\
248(48) \\
131 \cdot 7(18 \cdot 6) \\
54 \cdot 4(5 \cdot 7) \\
54 \cdot 5(7) \\
97 \cdot 5(11) \\
127 \cdot 4(17 \cdot 6) \\
42(10 \cdot 3)\end{array}$ & $\begin{array}{l}29(5) \\
189(28 \cdot 1) \\
196 \cdot 6(28 \cdot 6) \\
62 \cdot 1(9 \cdot 9) \\
424(63) \\
212(26 \cdot 9) \\
302 \cdot 1(36 \cdot 6) \\
192(24 \cdot 7) \\
10 \cdot 5(2 \cdot 3) \\
143(23 \cdot 6) \\
26 \cdot 7(3 \cdot 9) \\
34 \cdot 7(5 \cdot 5) \\
46(7 \cdot 6) \\
67 \cdot 3(7 \cdot 6) \\
354(97 \cdot 8) \\
104(12 \cdot 1) \\
62 \cdot 1(3 \cdot 7) \\
65 \cdot 4(11 \cdot 6) \\
84 \cdot 8(11 \cdot 9) \\
118 \cdot 1(24 \cdot 1) \\
34 \cdot 7(11 \cdot 7)\end{array}$ \\
\hline
\end{tabular}

Values: mean (SE) $\mu \mathrm{mol} / \mathrm{l}$.

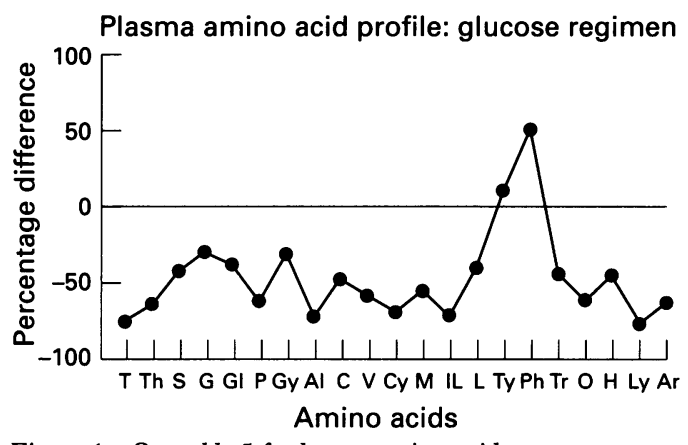

Figure 1 See table 5 for key to amino acids.

Plasma amino acid profile: glucose/amino acid regimen

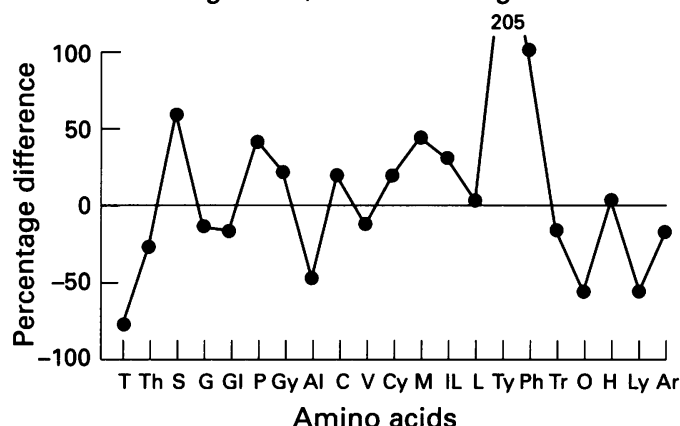

Figure 2 See table 5 for key to amino acids.

Plasma amino acid profile: glucose/amino acid/lipid regimen

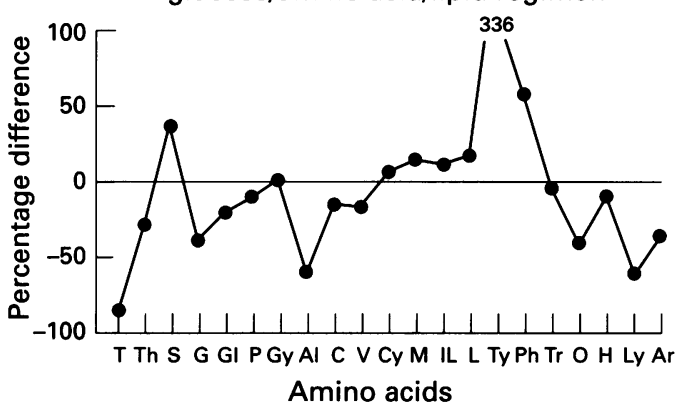

Figure 3 See table 5 for key to amino acids.

low plasma amino acid concentration and negative nitrogen balance is hazardous to the infant either at the time or in the longer term remains uncertain.

This study confirmed previous reports that the amino acid solution used in this study is associated with substantially increased values of tyrosine and phenylalanine. ${ }^{9}$ It has been suggested that high concentrations of phenylalanine occur more commonly when the ratio of total energy intake to protein energy intake is low. ${ }^{26}$ Although the same study was unable to demonstrate an association between increased plasma phenylalanine and impaired mental development, motor development, or social maturity at 18 months of age, we agree with the view that a reduction in intake of

Table 6 Plasma triglyceride and cholesterol concentrations immediately after birth and towards end of study regimens

\begin{tabular}{lllll}
\hline & \multicolumn{2}{l}{$\begin{array}{l}\text { Plasma triglyceride } \\
\text { mmoll (SE) }\end{array}$} & \multicolumn{2}{l}{$\begin{array}{l}\text { Plasma cholesterol } \\
\text { mmoll (SE) }\end{array}$} \\
\cline { 2 - 6 } Regimen & Before & After & Before & After \\
\hline a & $0.43(0.07)$ & $0.40(0.04)$ & $1.71(0.31)$ & $1.60(0.29)$ \\
b & $0.38(0.11)$ & $0.35(0.06)$ & $1.11(0.25)$ & $1.48(0.39)$ \\
c & $0.45(0.11)$ & $0.47(0.09)$ & $1.71(0.16)$ & $1.64(0.2)$
\end{tabular}


phenylalanine and tyrosine for preterm infants would be advisable. The amino acid solution was not supplemented with taurine, and the plasma taurine concentrations were very low in each of the three groups. As the ability of preterm infants to synthesise taurine is limited, taurine has been added to more recently marketed amino acid solutions. ${ }^{9}$

In low birthweight infants the regulation of glucose homeostasis is extremely delicate and hypoglycaemia and hyperglycaemia are common. ${ }^{27}$ In addition to glucose intake, other determinants of plasma glucose instability at this time include variability in energy expenditure; immaturity of glucoregulatory mechanisms ${ }^{28}$; endogenous glucose production, which, in contrast to adults, is not suppressed in the newborn period by exogenous glucose infusion $^{29}$; and increased plasma free fatty acid concentrations, which can occur during fat infusion, and which may inhibit glucose utilisation. ${ }^{30}$ In our study hypoglycaemia occurred most frequently in the (b) group and least commonly in the (c) group. This may be related to the energy intake of the glucose/ amino acid group not meeting the energy cost of increased protein synthesis following the administration of amino acids. ${ }^{31}$ The measures which were taken to treat hypoglycaemia resulted in there being no significant difference in the centiles for plasma glucose for each of the three feeding regimens.

The plasma triglyceride and cholesterol concentrations were similar in each of the three groups, indicating that the dose of lipid prescribed ( $1 \mathrm{~g} / \mathrm{kg} /$ day) was within the infant's capacity to hydrolyse triglyceride. Free fatty acid concentrations were not measured in this study and therefore whether the fatty acids were effectively metabolised was not determined. Brans and colleagues demonstrated that during the first four days of life of very low birthweight infants, triglyceride and free fatty acid concentrations remained within an acceptable range if the dose of lipid did not exceed $3 \mathrm{~g} / \mathrm{kg} /$ day. ${ }^{32} \mathrm{In}$ another study of low birthweight infants who were given $1 \mathrm{~g} / \mathrm{kg} /$ day on day 1 of life, increased to $3 \mathrm{~g} / \mathrm{kg} /$ day by day 4, triglyceride and fatty acid concentrations were similar to those obtained in infants who did not receive lipid until day $8 .^{18}$ There is evidence that essential fatty acid deficiency is more likely to occur in infants fed glucose and amino acid solutions compared with infants receiving glucose alone and therefore if amino acids are being administered the provision of at least maintenance fat requirement is recommended. ${ }^{20}$

The activity of lipoprotein lipase, the enzyme responsible for the hydrolysis of intravenous triglyceride, has been shown to be independent of intake, ${ }^{33}$ and therefore it has been suggested that the practice of slowly increasing fat emulsion during the introduction of parenteral nutrition is unnecessary. In support of this, there is evidence that newborn infants adapt very rapidly to intravenous fat administration, fat oxidation becoming the main source of energy within hours of starting fat infusion. ${ }^{34}$ That study also showed that the ability of the newborn to metabolise exogenous fat is not influenced by caloric intake, and therefore a period of high caloric intake of glucose and amino acids is not an essential prerequisite to the administration of a full dose of fat emulsion. In our study the infants who received $1 \mathrm{~g} / \mathrm{kg} /$ day of fat emulsion not only received an additional source of energy which placed them in positive energy balance, according to recent energy expenditure data on sick preterm infants, ${ }^{35}$ but also fulfilled their essential fatty acid requirements. ${ }^{36}$

Premature birth deprives infants of the continuous infusion of glucose, fatty acids, and amino acids which they receive in utero and which contributes to the massive accretion of nutrients during the last trimester of pregnancy. ${ }^{37}$ Data from this study indicate that restriction of the nutritional intake of preterm infants immediately after birth may cause clinically important metabolic disturbance. Whether this nutritional insult, occurring at such a critical period of infant development, has longer term consequences is not known. ${ }^{6}$ In a study of the brain growth of beagle puppies it was shown that after 10 days of either normal feeding, TPN, or $10 \%$ glucose, normal brain mass and cell number were demonstrated in the TPN group, but not in those puppies receiving glucose alone. ${ }^{38}$

This study shows that infants can tolerate intravenous macronutrients immediately after birth and neonatal parenteral nutrition regimens should be further refined to meet the specific needs of sick preterm infants, and ensure that the transfer from fetal to postnatal life is achieved with the minimum of interruption to nutrient provision.

We gratefully acknowledge support for this study from the Chest, Heart and Stroke Association (Scotland) and the Scottish Home and Health Department.

1 Menon G. Parenteral nutrition for the neonate. $B r f$ Intensive Care 1992; 1: 187-92.

2 Shaw JCL. Parenteral nutrition in the management of sick low birthweight infants. In: Gluck L, ed. Respiratory disorders in the newborn. Pediatric Clin North Am 1973; 20: orders in

3 Cockburn F. Intravenous feeding of the newborn. Clin Endocrinol Metab 1976; 5: 191-219.

4 Gill A, Yu VYH, Bajuk B, Astbury J. Postnatal growth in infants born before 30 weeks gestation. Arch Dis Child 1986; 61: 549-53.

5 Gunn T, Reaman G, Outerbridge EW, Colle E. Peripheral total parenteral nutrition for premature infants with respiratory distress syndrome: a controlled study. $\mathcal{f}$ Pediatr 1978; 92: 608-11.

6 Lucas A. Does early diet program future outcome? Acta Paediatrica Scandinavica 1990; 365 (suppl): 58-67.

7 Heird WC, Dell RB, Driscoll JM, Grebin B, Winters RW. Metabolic acidosis resulting from intravenous alimentation mixtures containing synthetic amino acids. $N$ Engl $\mathcal{f}$ Med 1972; 287: 943-8.

8 Johnson JD, Alberitton WL, Sunshine P. Hyperammonaemia accompanying parenteral nutrition in newammonaemia accompanying par

9 McIntosh N, Mitchell V. A clinical trial of two parenteral nutrition solutions in neonates. Arch Dis Child 1990; 65: 692-9.

10 Andrew G, Chan G, Schiff D. Lipid metabolism in the neonate II. The effect of intralipid on binding in vitro and in vivo. $\mathcal{F}$ Pediatr 1976; 88: 279-84

11 Pereira GR, Fox WW, Stanley CA, Baker L, Schwartz JG. Decreased oxygenation and hyperlipidaemia during intravenous fat infusions in premature infants. Pediatrics 1980; 66: $26-30$.

12 Hulman G, Levene M. Intralipid microemboli. Arch Dis Child 1986; 61: 702-3.

13 Sosenko IRS, Innis SM, Frank L. Intralipid increases lung polyunsaturated fatty acids and protects newborn rats from oxygen toxicity. Pediatr Res 1991; 30: 413-7.

14 Uauy R, Birch E, Birch D, Peirano P. Visual and brain function measurements in studies of n-3 fatty acid requirements of infants. $\mathcal{F}$ Pediatr 1992; 120: S168-80. 
15 Carlson SE, Cooke RJ, Rhodes PG, Peeples JM, Werkman SH. Effect of vegetable and marine oils on blood arachidonic and docosahexaenoic acids in preterm infant formulas. F Pediatr 1992; 120: S159-67.

16 Cooke RJ, Zee P, Yeh Yu-Yan. Essential fatty acid status of the premature infant during short-term parenteral nutrition. F Pediatr Gastroenterol Nutr 1984; 3: 446-9.

17 Saini J, MacMahon P, Morgan JB, Kovar IZ. Early parenteral feeding of amino acids. Arch Dis Child 1989; 64: $1362-6$

18 Gilbertson N, Kovar IZ, Cox DJ, Crowe L, Palmer NT. Introduction of intravenous lipid administration on the Introduction of intravenous lipid administration on the
first day of life in the very low birth weight neonate. first day of life in the very
$f$ Pediatr $1991 ; 119: 615-23$.

19 Snyderman SE, Holt LE Jr, Norton PM, Roitman E. Effect of high and low intakes of individual amino acids on the plasma aminogram. In: Leatham M, ed. Protein nutrition and free amino acid patterns. New Brunswick, NJ: Rutger University Press, 1968: 128.

20 Anderson TL, Muttart CR, Bieber MA, Nicholson JF, Heird WC. A controlled trial of glucose versus glucose and amino acids in premature infants. $\mathcal{F}$ Pediatr $1979 ; 94$ 947-51.

21 Mehta A. Prevention and management of neonatal hypoglycaemia. Arch Dis Child 1994; 70: F54-65.

22 Rivera A, Bell EF, Bier DM. Effect of intravenous amino acids on protein metabolism of preterm infants during the first three days of life. Pediatr Res 1993; 33: 106-11.

23 Mitton SG, Caldern AG, Garlick PJ. Protein turnover rates in sick, premature neonates during the first few days of in sick, premature neonates during
life. Pediatr Res $1991 ; 30: 418-22$

24 Heird WC. Parenteral feeding. In: Sinclair JC, Bracken $\mathrm{MB}$, eds. Effective care of the newborn infant. Oxford: Oxford University Press, 1992: 141-60.

25 Malloy HH, Rassin DK, Heird WC, Gaull GE. Plasmacerebrum amino acid relationships during total parentera nutrition. Pediatr Res 1979; 13: 404-9.

26 Lucas A, Baker BA, Morley RM. Hyperphenylalinaemia and outcome in intravenously fed preterm neonates. Arch Dis Child 1993; 68: 579-83.

27 Cowett RM. Pathophysiology, diagnosis, and management of glucose homeostasis in the neonate. Curr Prob Pediatr 1985; 15: $1-47$

28 Van Goudoever JB, Sulkers EJ, Chapman TE, Carnielli VP, Efstatopoulos T, Degenhart HJ, et al. Glucose kinetics and glucoregulatory hormone levels in ventilated preterm infants on the first day of life. Pediatr Res 1993; 33: 583-9.

29 Cowett RM, Oh W, Schwartz R. Persistent glucose production during glucose infusion in the neonate. $\mathcal{f}$ Clin Invest 1983; 71: 467-75.

30 Thiebaud D, DeFronzo RA, Jacot E, Golay A, Acheson K Maeder E, et al. Effect of long chain triglyceride infusion on glucose metabolism in man. Metabolism 1982; 31: on glucose

31 Young VR, Yu Y-M, Fukagawa NK. Protein and energy interactions throughout life. Acta Scand 1991; 373

(suppl): 5-24.
32 Brans YW, Andrew DS, Carrillo DW, Dutton EP, Menchaca EM, Puleo-Scheppke BA. Tolerance of fat emulsion in very low birth weight neonates. $A m \mathcal{F} D i$ Child 1988; 142: 145-52.

33 Forget PP, Fernandes J, Haverkamp Begemann P Utilisation of intravenous fat emulsion during total parenteral nutrition in children. Acta Paediatrica Scandinavica 1975; 64: 384-8.

34 Pierro A, Carnieli V, Filler RM, Smityh J, Heim T. Metabolism of intravenous fat emulsion in the surgical newborn. $\mathcal{F}$ Pediatr Surg 1989; 24: 95-102.

35 Forsyth JS, Crighton A Low birthweight infants and total parenteral nutrition immediately after birth. I. Energy parenteral nutrition immediately after birth. I. Energy expenditure and respiratory quotient of ventilated and

36 Ghisolfi J, Garcia JJ, Couvaras O, Thouvenot J-P. Metabolic utilisation of linoleic acid from fat emulsion in infants during total parenteral nutrition. $\mathcal{f}$ Parenteral Enteral Nutr 1988; 12: 387-91.

37 Widdowson EM, Dickerson JWT. Chemical composition of the body. In: Comar CL, Bronner F, eds. Mineral meta bolism. New York: Academic Press, 1964: 1-247.

38 Heird WC, Bieber MA, Bassi J, Pulito AR, Brasel JA. Effects of total parenteral nutrition (TPN) on brain growth of beagle puppies. Pediatr Res 1976; 10: 135. 